\title{
VEZETÉSTÖRTÉNETI PARADIGMÁK FEJLŐDÉSE JAPÁNBAN
}

A tanulmány a japán vállalatvezetés kialakulásával, történelmi és társadalmi gyökereivel, valamint intézményesülésének vizsgálatával foglalkozik. Elsố részében a szerzố áttekinti, milyen fóbb földrajzi és történelmi tényezók, körülmények játszottak szerepet a japán vezetési gyakorlat formálódásában. Ezt követôen egy meghatározott történelmi idôsíkon követi nyomon az amerikai menedzsmenttörténet egyes korszakainak megfelelố japán változásokat, vállalatvezetési reakciókat - kezdve a klasszikus menedzsment tanaitól (taylorizmus, racionalizálás...) egészen a mai kor globális versenye által támasztott követelményekig. Rámutat arra, mikor és miért késtek fontos váltások Japánban a vállalatvezetésben élenjáró Amerikához képest, majd értékeli ennek elméleti és gyakorlati jelentôségét. Szándéka szerint ez a történelmi áttekintés képez alapot napjaink Japánnal kapcsolatos gazdasági-társadalmi eseményeinek, reformjainak értékeléséhez is."

Kulcsszavak: menedzsmenttörténet, japán menedzsment, taylorizmus, emberi viszonyok, szervezeti struktúra, globális verseny

Az 1990-es évek óta a japán vállalatok többségére és a vállalatvezetés japán módszertanára komoly nyomás nehezedik. A változtatás igénye több tényezô miatt is megfogalmazható: a fejlődő japán gazdaság szükségleteinek megfelelóen kialakult menedzsmentmodellnek most egy világviszonylatban is a legerósebbek közé tartozó nemzetgazdaságot kell kiszolgálnia, az 1980-as évek buborékjának kipukkanása óta az állandó növekedés húzóereje megszúnt, az államadósság folyamatosan nô a munkanélküliséggel együtt, a külkereskedelmi mérleg egyenlege viszont egyre romlik e távol-keleti országban. A külföldi befektetók igényei is az átláthatóbb, és kevésbé szövevényes belsố viszonyok intézményesítése felé kényszerítik a vállalatokat. Ugyanakkor az öregedő társadalom nagyban hozzájárul a szociális feszültségek erôsödéséhez.

Úgy túnik, a japán társaságirányítási és vállalatvezetési modell napjainkban is átalakulóban van, és ez a jelenség izgalmas kérdéseket vet fel a menedzsmentkutatók számára: Japán jellegzetes nagyvállalatainál milyen vállalatvezetési gyakorlat válik majd dominánssá? Hova helyeződnek a hangsúlyok a biztonság/ kockázatvállalás, a stabilitás/innováció vagy az érintett/tulajdonosi szemlélet terén? A vállalati reformok iránya még nem egyértelmúen tisztázott, a történeti múlt vizsgálata azonban komoly segítséget nyújthat a jövôbeni változások előrejelzéséhez.

A cikk elsố részében sorra vesszük azokat a jelentôsebb tényezóket (földrajzi, kulturális, társadalmi, politikai adottságokat), amelyek a japán vállalatok menedzsmentjének kialakulására leginkább hatással voltak. Ezt követôen azt vizsgáljuk meg, hogyan fejlódött a japán nagyvállalatok termelési rendszere, stratégiája, valamint szervezeti magatartási elemei és struktúrája. Ennek során rámutatunk a tudományos vezetés, az emberi viszonyok tana, a szervezeti strukturális megújulás, továbbá a globális verseny paradigmáinak a japán menedzsmentet érintő hatásaira, befolyására. ${ }^{1}$

\section{A japán vállalati menedzsment fejlődését meghatározó környezeti tényezók}

Az alábbiakban felsorolt elemeknek kontextuális jelentőségük volt a japán menedzsment kialakulása szempontjából. Joggal vélhetô, hogy amíg érvényesek maradnak és hatnak, hozzájárulnak a vállalatvezetési kultúra és gondolkodásmód fenntartásához, konzerválásához is. 


\section{Szúk élettér, \\ pusztító földrajzi adottságokkal}

A japán szigeteket két kôzetlemezrendszer tektonikus mozgása és ütközése hozta létre: ez megmagyarázza a gyakori földrengéseket és a hegyekben gazdag vidéket (Totman, 2005). A fó szigetek ráadásul egy szélcsatornában helyezkednek el, amelyben minden ősszel erôs szélviharok (tájfunok) söpörnek végig. Köztudomású, hogy az ország felszínének háromnegyedét lakhatásra alkalmatlan hegyek borítják, azaz nagy népessége szúk területen összpontosul. Japán speciális földrajzi adottságainak következményei azonban messze túlmutatnak a nagy népsúrúségen.

Mindenekelốtt a természeti katasztrófák általánosak Japánban; a szökőárral járó Tohoku földrengés és a fukushimai nukleáris tragédia fájdalmasan emlékeztettek erre a körülményre. Társadalmuk kialakulásának kezdetei óta a japánoknak számolniuk kellett azzal a veszéllyel, hogy valamennyi materiális vívmányuk elpusztulhat, s ennek következményeként meglehetősen „szívós” gondolkodásmód alakult ki bennük. A válságok „gondoskodnak” a megújulásról, az innovációról minden egyes társadalomban, és emiatt a japán katasztrófáknak - szörnyú következményeik mellett - megvan az az „előnyük”, hogy a japán eszközök és technológiák képesek a lehető legmodernebb szinten maradni.

A kormány statisztikai adatai szerint Japán 2009ben a GDP 0,05\%-ának megfelelő összegú veszteséget szenvedett el az akkori katasztrófák miatt, de a kár okozta veszteség elérte a 2\%-ot 1995-ben, a kobei földrengés évében, és valószínúleg még magasabbra rúgott 2011-ben, a Tohoku földrengés következményeként.

Japán speciális földrajzi helyzete párosul a természeti erôforrások hiányával is. Az ország viszonylag kis területe megakadályozta a nagyüzemi mezőgazdaság kialakulását, és „,helytakarékos” városok kialakulásához vezetett; emellett az eróforrások korlátozott mennyisége önmegtartóztatásra késztette mind az egyéneket, mind a termelővállalatokat (Marosi, 2003; Vaszkun, 2010).

A szúkösség következménye ezen túl például a közlekedési rendszer szerkezete is: kialakulása óta a japán úthálózat lényegében semmit nem változott. A közlekedés forradalmasítása során - amit a vasútépítési hullám indított el - a síneket a már létezô, kiépített utak mellett fektették le, megerôsítve ezzel a feudalizmusból öröklött elosztási rendszert. Japánban a vasútépítés így nem kérdőjelezte meg a már meglévő vállalati szervezeti struktúrákat, míg az USA-ban újrarajzolta a gazdasági viszonyokat (Fruin, 1994).

\section{Konfucianizmus és kollektivizmus}

A történelem folyamán a konfucianizmus filozófiáját és politikai gazdaságtanát számos japán központi kormányzat eróteljesen támogatta. A cél az volt, hogy megszilárdítsák a társadalmi és a politikai fejlődés alapjait. Az eredetileg Kínából származó konfucianizmus egy átfogó világkép, egyben összefüggő értékek csoportja, melyet fel lehet fogni úgy, mint kiváló eszközt arra, hogy erósítse az állampolgárok alá-fölérendeltségét a társadalmon belül, és megalapozza a pozitív hozzáállást a kemény munkavégzéshez és a kitartó tanuláshoz. Bellah (1957) szerint a konfucianizmus más elméleti rendszereknél erốteljesebben határozta meg a japán vállalati intézmények fejlődését, bár a buddhizmus hatása sem elhanyagolható. A konfucianizmust támogatták például a Tokugavák, illetve a Meidzsi-kormány is, és Ohtsu (2002) szerint még ma is hatással van az üzleti teljesítményre a harmónia, a hierarchia, a jóindulat, a húség és a hosszú tanulás értékein keresztül.

A kollektivizmust (mely nem egyenlő a konfucianizmussal) bizonyos szempontból tekinthetjük az egyenlőség és a csoporthoz tartozás értékeinek kombinációjaként. A globalizáció hatásai a társadalmakat az individuális értékek felé mozgatják, és néhány tudós máris tagadja, hogy a japán kollektivistább szellemú nemzet lenne a többinél (Matsumoto, 2002). A japán és a nyugati társadalmi rendszerek között az egyik szembetúnő különbség, hogy „Nyugaton” az egyének a szerződése(ke)n alapuló tevékenységeik alapján integrálódnak a társadalomba, a japánok viszont valamilyen csoporthoz való tartozás révén válnak a társadalom részévé. Ilyen csoportok például a vállalatok (Maruyama, 1997).

Számos eszközt és módszert találhatunk ma, melyek alkalmasak az egyes emberek közti együttmúködés előmozdítására, vagy a nemkívánatos viselkedési formák (mint például az ún. potyautas magatartás) kiszúrésére. Cégek közötti szerveződés esetén a becsületességen túl a csoport tagjainak meg kell próbálniuk legalább a piaci árakat és minőséget nyújtani a csoporton belüli értékesítés során, különben megkérdőjeleződhet a csoporthoz tartozásuk. Ugyanebból az indíttatásból a kölcsönös függéssel járó beruházásokat is pozitívan ismeri el a csoport, ami egyfajta „kreatív feszültséghez” vezet (Itami - Roehl, 1987).

A kollektivizmus eszméje azt sugallja, hogy az egyén életének értelmét valamilyen csoport, illetve a csoporthoz való tartozás képezi. A japán intézmények axiómája, hogy egy-egy csoport, kisebb-nagyobb közösség mindig fontosabb, mint az egyén, vagy akár mint több, egymástól független egyén halmaza. Az iskolában a tanulók nemcsak egy bizonyos szintú le- 
xikális tudást sajátítanak el, hanem egyidejúleg „a csoport részeként való gondolkodás, kommunikáció és viselkedés" képességét is (Fujimura, 2006: p. 108.). Abe (2010) szerint ennek a csoporttudatnak és az ebból fakadó demokratikus vezetési stílusnak három alapvetố célja van: (1) az irigység, féltékenység és a szükségtelen versengés visszaszorítása, (2) a holisztikus szemlélet kialakítása és az együttmúköódés elôsegítése, valamint (3) a kétirányú, szabad kommunikáció támogatása a különbözô szervezeti egységek és pozíciók között.

A kollektivista, avagy csoportkultúra következményei a vállalatoknál sokrétúek. A munkafolyamat közben elkövetett hibánál például a csoport az egyént a közösség erejével és (néha irracionális) mentségeivel védi, akár súlyosabb esetekben is (ez nem azért van, mert úgy gondolják a csoportban, hogy igaza van, hanem azért, mert a hibázó egyén is közülük való). Másfelól, ha valakit megbélyegeznek, mert a véleménye a csoportéval ellentétes, ez általános érvényưvé válik és a többség kiközösíti: az illető egyén elveszíti a csoport védelmét (Nakane, 1970).

Fontos jellegzetesség Japánban, hogy az egyenlőségen alapuló kollektivista csoportgondolkodást kombinálják a konfucianizmus alá-/fölérendeltségi szellemiségével, így az életkor, a nem és a végzettség is a hierarchia alapjává válik a szigorú csoporttudat ernyốje alatt.

\section{Késói iparosodás}

A történelemból ismerjük, miként szigetelték el a Tokugavák az országot az 1600-as évektől 1853ig, hogy jobban ellenôrzés alatt tarthassák a daimyokat (feudális földbirtokosokat). A XIX. század végén ugyan megindulhatott a gyors iparosodás, de a japánokban természetszerúen kialakult egyfajta kisebbrendúségi érzés a nyugati államokkal szemben, amelyeknek technológiai fejlettsége látványosan meghaladta a szigetországét.

Gerschenkron (1962) elmélete a késôi fejlódésról érvényes lehet Japánra is: azt állítja a szerzô, hogy a késve fejlődóknek jobban meg kell tervezniük és szervezniük az iparosodás folyamatát, ami magasabb szintû kölcsönös egymásra hatáshoz vezet politikai, gazdasági és szociális téren.

Japán késói fejlődésének számos kihatása volt az ipari tevékenységekre, a pénzügyi piacokra és intézményekre, valamint az egyes cégek stratégiájára és szervezeti struktúrájára. Dore (1973) kiemeli például az állam domináns szerepét, a cégek gyorsabb iparosodását és bürokratizálódását, továbbá a munkások emberként való kezelését. Jacoby (2007) azt is hangsúlyozza, hogy az I. világháború után Japán a gyors iparosodás felé mozdult el, de mindenképp el akarta kerülni a külföldön tapasztalt munkásmegmozdulásokat, s ez vezette a munkaadókat a tudományos vezetés és a jóléti kapitalizmus egyidejú adaptálása felé.

A Nyugattól való tanulás motivációja minden japán cégnél érzékelhetô volt, és ez a körülmény a kormánynak is legitim felhatalmazást adott a határozottságra a reformjaival kapcsolatban.

\section{Állami fejlesztések, védett piacok}

Az erós, intervenciós politika számos hatást gyakorolt Japán üzleti életére. Érdemes felhívni a figyelmet az állam szerepére a japán nagyvállalati keretek kialakulásában, illetve annak nemzetközi kihatásaira a világkereskedelemben és a japán cégek exporttevékenységében.

A Meidzsi-restauráció történelmi korszakában Japánnak számolnia kellett a gyarmatosítás kockázatával. Noha a japánok külföldi szakértőket hívtak az új technológiák elsajátításához, végsố céljuk mégis az volt, hogy a tanulási folyamat során a lehetô leghamarabb hazaküldjék óket, és folytassák a modernizációt „egyedül”, önmagukra támaszkodva. Ennek egyik eklatáns példáját szolgáltatta a vasútépítés, melynek során a Meidzsi-kormányzat sikeresen megakadályozta a külföldi tő́ke térnyerését - bár az elsố vasúti vonal megépítésénél még száznál több külföldi, elsôsorban brit vendégmunkás segédkezett (Imashiro, 1997).

A feudalizmus szigorú hierarchiája és a felzárkózásra hivatkozó állami bürokraták központosított hatalma idôvel fegyverkezésbe és az önállóság túlzott hangsúlyozásába torkollott, egészen a II. világháború végéig. Magától értetődő, hogy a háborús készülődés csak fokozta a központi hatalom súlyát Japánban. „Ezek alatt a pusztító évek alatt a bürokraták megszállták a mindennapi élet összes elképzelhetô területét, és cselekedeteiket háborús szükségszerúségként tüntették fel. A hatalom, amelyet névlegesen a parlament és a politikai pártok birtokoltak, légnemúvé vált a császári bürokraták diktatúraszerú nyomása alatt" (Miyamoto, 1995: p. 10.). A bürokraták hatalma kétségtelenül megmaradt a II. világháború után is mind a parlament fölött a törvényhozásban, mind pedig önkormányzati szinten, az amerikai megszállók törekvései ellenére. Miyamoto szavaival „,a helyi kormányzatok gyakorlatilag a központi közigazgatás és bürokrácia képviselőivé váltak" (12. old.).

A háborút követô erôs szabályozási törekvéseket jól példázza a MITI (Külkereskedelmi és Ipari Minisztérium) tevékenysége. Ezt a központi irányító szervezetet 1949-ben alapították, hogy intézményesítsék a japán kormány és a magánszektor együttmúködését és 
felgyorsítsák a gazdasági fejlődést. A MITI tevékenysége jól illusztrálja a „fejlesztő államot”, amely aktív szerepet játszik a gazdasági szabályozásban és fejlesztésben olyan eszközökkel, mint például az erôs támogatások és újraelosztások rendszere, az ötéves tervek, a befektetési „tanácsok” magáncégeknek (,window guidance”), az olcsó iparfinanszírozás a Japán Fejlesztési Bankon keresztül, az import kiszorítása, valamint az innováció és az export támogatása (Black, 2010; Fruin, 1994; Johnson, 1982; Móczár, 1987). Feltehetóen a japán bürokrácia „mindig is abból indult ki, hogy az államkapitalizmus (azaz a bürokrácia által irányított gazdaságpolitika) a leghatékonyabb módja egy ország felzárkóztatásának. A II. világháború utáni japán gazdasági csoda azt bizonyítja, hogy igazuk volt a bürokratáknak" (Miyamoto, 1995: p. 13.).

Japán világkereskedelmi és a nemzetközi üzleti életben betöltött pozícióját már hosszabb ideje a WTOtagsága határozza meg, bár még mindig vannak jelentős mentességei és importkorlátozó intézkedései.

A legutóbbi évszázadban a piacok állami védelme a háborús gazdálkodás és a háború utáni helyreállítás alatt (a MITI-korszakban) csúcsosodott ki. Az első „támadások" a külföldi kereskedôszervezetektôl és Japán OECD-tagságával érkeztek. A liberalizációs mozgás lassan bontakozott ki, öt hullámban, az 1960-as és az 1970-es évek között, miközben a szoros ellenőrzés a külföldi befektetések (FDI) és az import vonatkozásában némileg enyhült (Hamada, 1991). A külföldi befektetések szabadságát végül 1980-ban legalizálták a külkapcsolatokat szabályozó törvényben.

A külföldi tốke részesedése a japán vállalatokban különösen az 1990-es évek után kezdett növekedni. Ahmadjian és Robins (2005) azt hangsúlyozza, hogy a külföldi befektetôk kétségkívül szerepet játszottak a hagyományos, ún. érintetti (stakeholder) kapitalizmus meggyengülésében. Olcott (2011) számos példát említ, amelyek bizonyítják, hogy a külföldi tôke elnyomja a japán tradíciókat, bár nem tudta igazolni teljesen a hipotézist, miszerint a nyugati tulajdonba került cégek elvetették volna a jelen tanulmányban is tárgyalt, klasszikus japán vezetési módszereket és elveket. Összegzésként elmondhatjuk, hogy Japán protekcionista „hitvallói” még mindig a tradíciók megőrzésén munkálkodnak, ugyanakkor az országra egyre erôsebb nyomás nehezedik azért, hogy külföldi „best practice” megoldásokat építsen be intézményrendszerébe.

A világháborút követố idôszakban Japán kihasználta a nyugati világ liberális kereskedelmi politikáját a GATT- és WTO-tagságának köszönhetően. Japán 1981 óta egészen a közelmúltig folyamatosan keres- kedelmi többletet mutatott ki, aminek eredményeként hatalmas devizatartalékokat halmozott fel. Úgy túnik, Japán partnerei napjainkra megelégelték a távol-keleti ország egyoldalú elónyeit - legalábbis ez túnik ki a WTO dohai fordulóján felmerült vitákból az agrárkereskedelmi reformmal kapcsolatban. A jelenleg is zajló TPP (Trans-Pacific Partnership) csatlakozási folyamata is számos példát szolgáltat a többoldalú kereskedelmi tárgyalások komplexitására és nehézségeire.

\section{Folyamatos gazdasági növekedés}

A japán gazdaság életpályáját erôsen átrajzolta a II. világháborút követő, figyelemre méltóan gyors talpra állás (Marosi, 1986). Míg a fegyverletétel idején az ipari termelés még az elsố világháború előtti szinten mozgott, a nemzeti reáljövedelem már átlagosan 10,8\%-kal nốtt 1946 és 1954 között.

Ennek köszönhetôen az ország újra elérte a háború elótti termelékenységi, nemzeti jövedelmi és fogyasztási szintet. Az 1955-öt követő tizenöt évben a növekedési ráta elképesztő szinteket ért el: 9,1\% volt 1960ig, 9,8\% 1960 és 1965 között, továbbá 12,1\% 1966-tól 1970-ig bezáróan (Pyle, 1996). Az elsố olajválság lelassította a japán gazdaságot is, de 1950 és 1973 között a reálnövekedés átlagosan több mint tíz százalékot mutatott - az amerikai növekedési ráta közel háromszorosát.

Az 1973-ig tapasztalt gyors gazdasági növekedés, majd az 1990-ig tartó stabil, lassú fejlődés észrevehetô hatást gyakorolt a japán cégekre és az általuk vallott vezetési filozófiára. Egyértelmúvé vált viszont, hogy a folyamatos növekedést nem lehet örökké fenntartani. Amint a szomszédos országokhoz képest a japán munkaerô drágulni kezdett, és megszorításokat alkalmaztak az exportpiacokon, a növekedés lendülete megtört: azóta egy többé-kevésbé stagnáló gazdaság jellemzi Japánt. A buborék kipukkanása óta a gazdaság teljesítménye számos területen alig éri el az 1989-es szintet. A reál GDP növekedése 5-10\%-ról 1-2\%-ra esett viszsza 1990 után, a munkanélküliség pedig 2,1\%-ról az 5,4\%-os csúcspontra emelkedett 2002-ben. A föld- és a nyersanyagárak a töredékükre estek: a Nikkei 225 index az 1989-es 38.916-ról 2002-re 8.579-re zuhant vissza, míg a föld árának indexált értéke a hat legnagyobb japán városban az 1990-es 100-ról 2002-re 30,4re csökkent (Keizer, 2011). Az 1996-os évben elért kimagasló GNP fóleg a támogató kormányzati költekezésnek köszönhető, nem pedig a gazdaság természetes dinamikájának (Benson, 2006). Nyilvánvaló, hogy Japán üzleti lehetőségei módosultak, a növekedés már nem adottság, így a gazdaság szerkezetének reagálnia kell a változásra. 


\section{A japán vállalatvezetési rendszer történelmi fejlődése}

\section{Iparosodás: a feudalizmustól a modern japán vállalatig}

Japán 1867-ben még feudális ország volt archaikus, a mezőgazdaságot középpontba állító kormányzati rendszerrel, miközben Nyugat-Európa államai vagy az USA már a tömegtermelés és a második ipari forradalom felé meneteltek.

A korábbi szamurájokból alakult kormány 1868-at követően jelentős reformokat kezdeményezett a politikai, üzleti és társadalmi rendszer egészének átalakítására. Az első modern vállalatok, a zaibacuk 1885 körül jelentek meg, amikor az akkori pénzügyminiszter, Macukata számos állami ipari vállalatot privatizált (Hirschmeier, 1981). Ez nyilvánvalóan késớinek számító időpont a Nyugattal összehasonlítva, de a japán vállalatok rendkívül gyors fejlődésnek indultak (Fruin, 1994). Korai stratégiájuk elsốdlegesen a vállalatközi tranzakciókon alapult és diverzifikáltak, azaz inkább választék-, mint méretgazdaságosságra törekedtek, mivel a tömegtermelés kibontakozása a XIX. század végén még akadályokba ütközött.

Ennek a méretgazdaságossági hiányosságnak az egyik oka a technológia volt, amit a már iparosodott nyugati országokból kellett importálni (kb. évszázados lemaradásban Nyugat-Európával összehasonlítva). A Meidzsi-kormány különféle tanulmányutakat szervezett az adminisztratív irányító szervek hivatalnokai számára, továbbá külföldi szakértőket hívott meg és ösztöndíjakat alapított, hogy támogassa a japán diákok külföldre utazását. Az 1900-as évektól kezdve az ipari tevékenységek, szektorok jelentôs részét átalakították a nyugati technológia alapján, de sajátos módon az elóállított termékek forgalmazását a hagyományos, több száz éves nagy- és kiskereskedelmi hálózatokon keresztül bonyolították tovább (Fruin, 1994). Ennek következményeképp a termelés és az elosztás napjainkban is gyakran elkülönül egymástól, ez utóbbi tevékenységet ugyanis a nagy nemzetközi hálózattal is rendelkezố japán kereskedőházak végzik.

$\mathrm{Az}$ elmaradott technológián kívül képzett munkaeróból is hiány volt a szigetországban, így ebben a tekintetben a japán és az amerikai gyárak a taylorizmus elterjedése elótt hasonló módon fejlődtek. A termelési eszközök birtokosaiból, a gyárak tulajdonosaiból gyakran hiányoztak a szükséges múszaki és vezetési képességek, ezért tapasztalt múvezetóket (ojakata) szerződtettek. Hasonlóan Amerikához, az utóbbiak hatáskörébe tartozott a munkaerő-felvétel, a képzés, az elbocsátás, illetve a munkafolyamatok és a munkafeltételek fel- ügyelete (Dore, 1973; Tsutsui, 1998). A korai japán termelés valójában az ojakaták képességeitől függött.

A tömegtermelés másik akadályát a kisméretú piacok jelentették. A feudalista japán piac nem volt eléggé kiterjedt ahhoz, hogy támogassa a magas szintú termelést az elsố iparvállalatok megalakulásakor, bár a kereslet gyorsan nôtt a háborús idôszakok következtében. 1894-95-ben Japán látványos gyôzelmet aratott Kína felett, domináns szerephez jutva ezáltal a térségben. Egy évtizeddel késóbb, 1904-05-ben a japán hadsereg legyôzte Oroszországot is, 1910-ben pedig annektálta Koreát. Fontos piacokat szerzett az I. világháború alatt is, amikor a nyugati hatalmak figyelmét az európai hadszíntér kötötte le (Pyle, 1996). Egy kisebb dimenziójú „tömegtermelés” az 1910-es évektól indult el Japánban - három évtizeddel késóbb, mint Amerikában. A tömegtermelés hajnalán, 1880 körül, az amerikai népesség száma ötvenmillió körül mozgott, ami az 1910-es években, a tudományos vezetés (scientific management) kezdetekor 90 millió fölé emelkedett. A japán népesség az 1910-es években érte el az ötvenmillió fôt, a 90 milliót pedig csak az 1950-es évek közepén - következésképpen a gyárak fordista módon történố átszervezése, valamint a munka előrehaladott gépesítése is csak három évtized késéssel jelent meg. Tsutsui szerint ,az elégtelen tốke, a bőséges munkaeró és a bizonytalan piacok feltételei között a nagy termelékenységú, magas múszaki színvonalú szerelószalag a legtöbb japán cég számára alkalmatlan modellnek bizonyult" (1998: p. 67.).

\section{A vállalaton belüli termelési rendszer fejlödése}

A taylorizmust, noha az 1910-es években rendkívül népszerú volt, az 1920-as évek vége felé már elítélték Japánban, és a figyelem Németország, illetốleg a racionalizáció felé fordult. Ez a fejezet a taylorizmus fejlődését és a japán menedzsmentre gyakorolt hatását vizsgálja.

Taylor hatása Japánban és az Egyesült Államokban egyaránt megfigyelhető - bár a két hatás között fontos különbségek vannak. Japánba nem érkeztek ugyan bevándorlók tömegesen, viszont a csekély számú képzett munkavállaló és a rendelkezésre álló olcsó, de képzetlen munkaerő kétségkívül hasonlóságokat mutat a két ország között. A szakképzett vezetók túlzott hatalma korlátozta a termelési rendszerek fejlődését és a minôségi színvonal emelkedését, ami a menedzsereket alternatív megoldások alkalmazására késztette. A munkavállalók zavargásai is állandó nyomást jelentettek: a kína-japán háborút követően, de fóként az 1910-es évektól hatékony üzemszervezési megoldások bevezetésére ösztönözte a gyárak vezetőit (Gordon, 1998). 
Japán tehát nyilvánvalóan „késett” az iparosodással és a tömegtermelés széles körú bevezetésével. Amint átvették és alkalmazták viszont a nyugati technológiákat, továbbá megfelelő piacméret alakult ki, a tudományos vezetés módszereinek alkalmazása gyorsan megindult. Az eloorelépéshez hozzájárultak a Meidzsi-kormány által támogatott tanulmányutak, illetve az 1900-as évek elején az Egyesült Államokba nagy számban kiküldött japán diákok, diplomaták és üzletemberek nyitottsága. Taylornak „A tudományos vezetés alapelvei" (The Principles of Scientific Management) címen megjelent könyvét már korán, 1913-ban lefordították japán nyelvre, ám Taylor hatása már ezt megelôzóen is jelentősnek bizonyult. Megalakult a Japán Taylor Társaság, melynek néhány tagja a pszichológia tudományterületén tevékenykedett. Egyik legjelentősebbb képviselőjük Yoichi Ueno volt, akit a „hatékonyság atyjának” vagy „Japán Taylorának" is neveztek (Tsutsui, 2001). Az 1910-es és 1920-as évek során ő volt a taylorizmus legkitartóbb népszerúsítője, széles körú, szervezett és hosszan tartó mozgalommá fejlesztve annak elveit. Meglepó módon állami részról aránylag csekély közvetlen támogatás érkezett, bár az állami tulajdonú vállalatok az elsốk között voltak, amelyek átvették a tudományos vezetést és annak módszereit - így például a munkafolyamat tervezését és a standardizációt.

Ezt a korai „befogadást” nem lehet egyszerúen a japán társadalomnak a nyugati eszmék és technológiák iránti általános nyitottságával magyarázni. Az I. világháború előestéjén a széles közvélemény a katonai és állami kiadások csökkentését sürgette, a tudományos vezetés elvei és módszerei pedig jó lehetôséget kínáltak erre. Hasonlóan az Amerikában végbement eseményekhez, a munkás- és szocialista mozgalmak fejlódésnek indultak az orosz-japán háború után, amely mozgalmak számos új vezetési módszer bevezetését ösztönözték Japánban (Tsutsui, 1998).

Korai „sikerei” után a taylorizmus tovább fejlődött és hosszú karriert „futott be” különféle megnevezések alatt. Az orosz forradalom évében, 1917-ben, társaival együtt Toshiro Ikeda egy újságot adott ki Hatékonyság címmel, amit tekinthetünk a „hatékonysági mozgalom" kezdetének (Nakase, 1979). Ez az új mozgalom Taylor elveit sokkal szélesebb körben valósította meg, mint ahogyan azt az amerikai üzemszervezó maga elképzelte. Ennek során Japánban megtervezték a „leghatékonyabb konyhakialakítást”, „a leghatékonyabb golfütést”, továbbá a gyöngyhalászat „legbiztosabb módszerét" (Tsutsui, 1998).

Az 1920-as évek vége felé a japán nacionalizmus erôsödését, valamint a japán-német diplomáciai kap- csolatok intenzívebbé válását érzékelhette a világ. A tudományos vezetésre ráépült a német Rationalisierung, mozgalom, melyet Japánban Kaichiro Imaizumi kezdeményezett 1927-ben, a Nemzetközi Tudományos Vezetési Konferencia harmadik találkozójának évében (Nakase, 1979). A racionalizálás egy Németországból átvett munkaszervezési koncepció volt, amely jól illeszkedett a japán üzleti mentalitáshoz - különösen az államilag támogatott trösztök és kartellek esetében. A trösztök és kartellek intézményének alkalmazása amely formációkat az amerikaiak betiltották az 1940-es évek végén - bevett gyakorlat volt a japán üzleti életben azzal a céllal, hogy csökkentsék a tranzakciós költségeket és növeljék a hatékonyságot és a termelékenységet. A taylorizmushoz képest, amely vezetési rendszer a vállalatok és a gyárak szintjére koncentrált, a racionalizálási mozgalom az egész ipart, illetve a nemzetgazdaságot fogta át. 1930-ban a legnagyobb japán termelővállalatok egyharmada, 1954-ben pedig több mint a fele átállt a könnyúipari termelésról a nehéziparira, és az arány 1973-ra 63\%-ra nőtt (Fruin, 1994).

A mandzsúriai incidens (1931) kitörésekor a japán kormányzati szabályozás felerôsödött. Az ekkor elfogadott iparellenőrzési törvény (Major Industry Control Act) megerôsítette a nagy üzleti vállalkozások pozícióját. Az ipari racionalizálásért felelős kormányzati szervet beolvasztották az ellenőrzési hivatalba (Control Bureau). A tudományos vezetés koncepciójában ekkor már nem az ipari szervezetek elismert munkamódszertanát látták, hanem inkább az „ellenség” ideológiai rendszerét.

Mindezek ellenére ezek a mélyen gyökerezô elvek és a hatékonysági filozófia hatottak a II. világháború utáni idôszakban is. Ide sorolhatjuk például a Japánban 1957-tôl, amerikai mintára bevezetett teljes minőségellenőrzés (TQC - total quality control) módszereit (Fruin, 1994). Nagy jelentôségú volt továbbá az amerikai Deming és Juran közremúködése, akik szintén nagy hatással voltak a japán minőségbiztosítás fejlődésére (Tsutsui, 1996). A vállalatok folyamatosan tesztelték és vezették be (vagy vetették el) az új módszereket, minőség-ellenőrzési ötleteket, a hatékonyság és a versenyképesség javítása érdekében.

Annak ellenére, hogy csak néhány dokumentált eset tanúskodott a taylorista menedzsmentet, munkaszervezési módszereket közvetlenül ellenzó munkavállalókról (Tsutsui, 1998), a taylorizmus japán kritikájáról is említést kell tennünk. A legtöbb munkavállalói panasz az új javadalmazási rendszerre vonatkozott, a képzett szakmunkások is eróteljesen tiltakoztak a munkafolyamaton korábban élvezett hatalmuk elvesztése ellen. A kritikusok azt is kifogásolták, hogy a tudományos 
vezetés „lerombolja” a munka szépségét, növekvő individualizmushoz és kizsákmányoláshoz vezet, miközben normává teszi a túlórát és szélesíti a munkavállalói-tulajdonosi szakadékot. Nakatsumi már az 1920-as évek elején megjegyezte, hogy a taylori javadalmazási rendszer ,,a munkavállalók haszonmotívumára épít, következésképpen aláássa az erkölcsi értékeiket és a kölcsönös szolidaritás érzését, utat engedve ezzel az antagonizmus és a féltékenység felerôsödésének"(1922: p. 130.).

Más kritikusok arra hívták fel a figyelmet, hogy a taylorizmus bevezetésével elért ipari hatékonyságnövekedés hosszú távon túltermelést, majd azt követôen munkanélküliséget eredményez. Kritikájukat az 1929-ben kezdődött világválság csak felerősítette: a japán ipari többletkapacitás egészen 1936-ig folyamatossá vált, a munkanélküliek növekvố tömege erôs fékként hatott a vállalati reformok és mentốcsomagok terén (Tsutsui, 1998). Bár a taylorizmussal szembeni ellenállás korántsem volt olyan erós, mint Amerikában (vagy egyes nyugat-európai országokban), a kritikai észrevételek és a japán társadalmi-földrajzi sajátosságok olyan, ,kibővített” taylorizmushoz vezettek, amely felfogás sok tekintetben megfelelt az amerikai emberi viszonyok tana paradigmájának.

\section{A paternalizmus és az emberi tényezó Japánban}

$\mathrm{Az}$ amerikai menedzsment történetének szerves részét képezik az emberi viszonyok paradigma jóléti gyökerei, a hawthorne-i tanulságok (miszerint - ellentétben Taylor vélekedésével - a csoportteljesítmény nagyobb lehet, mint az egyéni teljesítmények összege), továbbá az emberi kapcsolatokat fejlesztô technikák kialakulása az 1920-as és '30-as években. Mindezen emberi tényezókkel a japán vállalatvezetốk kapcsolatba kerültek a megszállás alatt, sốt, az amerikaiak - japán segítséggel - be is vezettek HR-elemeket a II. világháború után (Tsutsui, 1998). Az új menedzsmentfilozófia természetesen felkeltette az érdeklődést Japánban, különösen a munkavállalók lelkesedésének köszönhető hatékonyságnyereségnek és a „békésebb” szakszervezeti életnek köszönhetôen. Néhány HR-módszer, mint például a javaslattételi rendszer vagy az attitúdfelmérések bevezetésre kerültek számos japán vállalatban is. Az emberi viszonyok tanának összhatása jelentősen elmaradt az Amerikában tapasztalt áttöréstôl: bírálói azt hangoztatták, hogy a japán iparnak nincs szüksége amerikai tanításokra a kommunikációban és a csapatmunkában (Tsutsui, 1998). A mi értelmezésünkben több ok is magyarázhatja a HR-paradigma tartózkodó fogadtatását.

Először is a jóléti szemlélet nem hiányzott oly mértékben a japán vállalatokból, mint Amerikában: a korai ipari vállalkozások nemzeti, vagy éppen politi- kai megfontolásokból jöttek létre. A japán iparosodás részleges következményeként a különféle feladatokat és felelôsségeket, melyek Nyugaton a kormányok kezében összpontosultak, Japánban azonnal magáncégekhez delegálták, melyek így „,a társadalmi jólét motorjaivá" váltak (Fruin, 1994: p. 308.). Ezek a szociális feladatok magukban foglaltak minden olyan juttatást, amiket a kormányzatnak biztosítania kellett, de nem volt meg az ehhez szükséges állami háttér: a japán vállalatok biztosították az oktatás egy részét, a lakhatást, az egészségügyi ellátást, a nyugdíjat, az utazási támogatást vagy a megélhetési költségkiegészítést. Már viszonylag korán, az 1920-as évektôl kezdődően több törvény gondoskodott az állam által közvetve nyújtott jóléti alapszolgáltatásokról, azaz a szociális biztonságról, az öregségi nyugdíjról, a munkanélküli segélyrôl, a balesetbiztosításról és a minimálbérról (Cole, 1973). Ennek egyik következménye, hogy Japánban az alkalmazottakat „vállalati embereknek” hívják: a munkaadó biztosítja a teljes megélhetésüket (családjukkal együtt), és a vállalatnál töltik el egész életüket (Marosi, 1985). A cég gyakran még az alkalmazottak feleségeinek iskoláztatását is biztosítja (Abegglen, 1960).

Másodsorban: a kollektivista Japánban nem akadt olyan vállalati vezetô, aki úgy gondolta volna az iparosodás hajnalán, hogy a munkavállalókat hatékonyabban lehet egyénileg vezetni, mint egy csoport tagjaiként. A taylorizmus elvetette a csoportos munkavégzést, míg a japán kollektivizmus nem is tudott másként gondolkodni. A tudományos vezetés elvei közül az egyéni munkavégzést a japánok kezdettól fogva elutasították (Tsutsui, 1998). A japán üzemi munkások például, akiknek lehetôségük volt saját munkamódszereik fejlesztésére, közvetlen ellenpólusai a taylorizmus elveit követô amerikai társaiknak, akik viszont kizárólag csak a mérnökök által előírt módszerekkel dolgozhattak. Az emberi viszonyok paradigmával, majd az 1960-as, '70es évektól meghonosodó „empowerment” koncepcióval azután az amerikai cégek is kezdték „,megkerülni” a munkafelügyelóket, és nagyobb autonómiát, döntési jogkört biztosítottak a munkásaiknak. Ezzel a gyakorlattal messzebbre mentek még a japánoknál is, ott ugyanis a termelést azért nagymértékben felülról jövő utasításokkal irányították, és a menedzsment prioritásaira helyezték a hangsúlyt (Liker et al., 1999).

Elmondható továbbá, hogy a személyközi kommunikációs képességek hiánya sosem volt jellemző Japánban: ezt az országot az érzelmek inkább jellemzik, mint a szavak, és az emberek megtanulták, hogyan értsék meg egymás gondolatvilágát anélkül, hogy „kibeszélnék" azokat. Sem az erősen hierarchizált japán nyelv, sem pedig a konfucianista szellem nem segíti 
az érzelmek (barátság, szeretet, gondoskodás) verbális megfogalmazását, de a japán filmek érzelgốssége sokat mond e tekintetben. Amint a szervezeti magatartás elméletei kialakultak Amerikában (Barnardnak, Likertnek, McGregornak, Argyrisnek és másoknak köszönhetóen), a japánok átvették és adaptálták azokat. Keys és Miller (1984) szerint ,a japánok sokkal fogékonyabbnak ítélték saját szervezeteiket a részvétel ezen formáját illetôen, mint az amerikai menedzserek" (343. old.). A japán vállalati vezetốk sokkal inkább elfogadták, hogy a munkavállalók képesek és készek részt vállalni a munka megszervezésében, továbbá hozzájárulni a támogató munkafelügyeleti légkör kialakításához. Ez az elköteleződés nemzetenként eltérő lehet; Lee (2000) szerint például a japán vállalatokban ,az empowerment erőteljesen beépült a cégek kultúrájába és menedzsmentjébe" (413. old.).

Összefoglalva: a fóáramú menedzsmentgondolkodás elismeri, hogy a HR-megközelítés a vállalatvezetés hasznos és szükséges eleme, viszont nem tekinti a tudományos vezetést helyettesító paradigmának. Tsutsui (1998) szerint bizonyítást nyert, hogy a HR-technikák és az emberközpontú retorika gyakorlati alkalmazása „egyértelmúen kompatibilis a tömegtermeléssel és a taylorista módszerekkel" (158. old.), nemcsak Japánban, hanem az USA-ban is - ellentétben a HR-támogatók elméleti állásfoglalásával. Ennek ékes bizonyítéka, hogy a Hatékonyság Japán Szövetsége egy éven belül kiadta mind Mayo munkájának, a The Human Problems of an Industrial Civilization-nek japán változatát, mind pedig Frank Gilbreth Cheaper by the Dozen címú könyvének újabb fordítását.

\section{A vállalat formális szervezeti struktúrájának fejlödése}

$\mathrm{Az}$ 1950-es években az amerikai vállalatok egy jelentékeny része elindult a nemzetköziesedés útján, aminek következtében belsô szervezeti struktúrájuk is átalakult és divizionálissá fejlődött (Vaszkun, 2012). Ez a fejlödés a vezetéstudomány elméleti támogatásához és a globális környezetben is helytálló menedzserek alkalmazásához vezetett. A szervezeti átalakulást az amerikai múködőtőke-befektetéseknek az európai országokba történó jelentôs mértékú beáramlása kísérte.

Ahogyan az 1. ábra mutatja, az 1980-as évekre Japánt is elérte a külföldi befektetések hulláma, ez idő tájt ugyanis az erôs jen ösztönözte a japán ipar kitelepülését. Ismét azt állapíthatjuk meg, hogy az új paradigma 30-40 évvel késóbb alakult ki Amerikához képest: Japán csak 1985 után került kapcsolatba igazán heterogén, változatos piaccal, annak ellenére, hogy vezetô nagyvállalatai már sokrétú, a külföldi piacokra és munkaeróre vonatkozó tudást halmoztak fel. Az 1980-as évek második feléig jellemzően a kereskedóházak exportáltak, a kihelyezett termelés még nem terjedt el annyira a japán gyakorlatban.

Itt amellett érvelünk, hogy a szervezeti strukturális megújulás késôn, és csak részben „érkezett meg” Japánba, ami egyértelmúen csökkentette a paradigma szervezési erejét és jelentőségét. A szervezeti struktúra központi szerepet játszik érvelésünkben - mégpedig a stratégiával együtt, hiszen Chandler (1962) óta tudjuk, hogy a termékválasztékra vonatkozó stratégia közvetlenül kapcsolódik a szervezeti formához. A nagyvállalatok alapvetően kétféle formális struktúrában múködnek: ezek a funkcionális és a divizionális szervezeti formák. ${ }^{3}$ Az elóbbi esetében a termelés ugyan helyi szinten szerveződik a gyárakban, de a marketing-, értékesítési, pénzügyi, logisztikai és kutatás-fejlesztési funkciók a gyárak és a vállalati központ között oszlanak meg, vagy a központ hatáskörében maradnak. A központi döntéshozatal a meghatározó, a felső vezetés irányításilag részt vesz az operatív munkafolyamatban. A multidivizionális szervezeti struktúrában az operatív termelőtevékenység teljes egészében a divíziók vezetésének irányítási hatáskörébe tartozik, azaz a felső vezetôknek több idejük marad a stratégiai távlatú tervezésre (Dobák, 1988).

Az előző fejezetben láttuk, hogy - bár divizionális szervezetek már az 1920-as évektól léteztek Amerikában - a decentralizáltabb forma fóként a szervezeti strukturális megújulás paradigmájának megjelenésével

1. ábra

FDI-kiáramlás Japánban, összehasonlítva az USA-val (1970-2010, milliárd dollár)

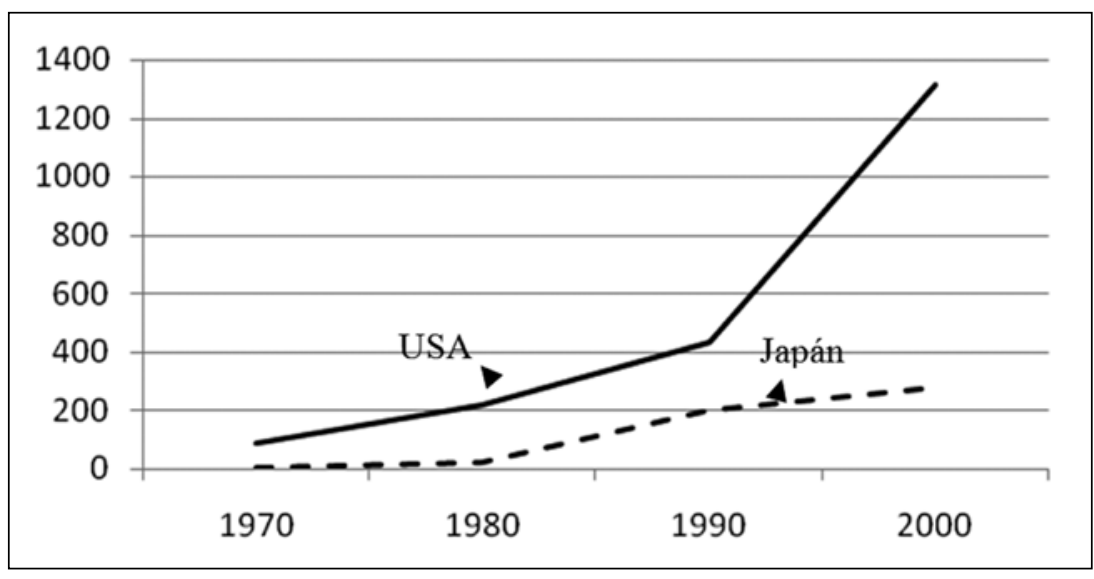

Forrás: UNCTAD 2006 Statisztikai Melléklet, idézve: Shinpo (2008: p. 111.) 
terjedt el az 1950-es és 1960-as években. Hasonló volt a helyzet Japánban is: a nyereségközpont gyakorlati alkalmazását Matsushita már 1932-ben bevezette, de ebben nem követte ốt a többi nagyvállalat (Miyamoto, 2008). A szigetország vállalatai ugyanis önmagukban nem kifejezetten nagy méretúek vagy komplex szerveződésúek, különösen az amerikai nagyvállalatokhoz képest. A kétszáz legnagyobb japán iparvállalat közül 1954-ben 77 számított divizionálisnak (azaz amelyek legalább három különbözô fő termékvonallal rendelkeztek), 1987-ben pedig 80 ipari szervezet. A kétszáz vállalat 40\%-a kötelezte el magát a korlátozott diverzifikáció mellett 1987-ben, illetőleg nem múködött olyan élvonalbeli japán vállalat, melyre a magas fokú diverzifikáció lett volna jellemző (Fruin, 1994).

Mielôtt tömeges export irányulhatott volna a nyugati piacok felé (a kései 1950-es években), a hazai és a legközelebbi kelet-ázsiai piacok nem bizonyultak elég kiterjedtnek, így a méretgazdaságon alapuló verseny kockázatos volt. Emiatt a háború elő́tti Japán kulcságazatai, például a hajógyártás, a vasúti berendezések gyártása vagy a távírógyártás nem a tömegtermelésre rendezkedtek be, noha a textil-, a fém- és az élelmiszeriparban sikerült bizonyos fokú mérethatékonyságot elérni. A zaibacuk ezért fóként a választékon alapuló gazdaságosság révén tudtak versenyben maradni, a késóbbi japán vállalatok pedig a diverzifikáció helyett inkább a méret- és választékgazdaságosság kombinálására törekedtek. Ahogyan Fruin megállapította, „megrekedtek” a hagyományos funkcionális szervezet keretei között, s a divíziók kialakítása helyett „termékfókuszú funkcionális egységeket létesítettek a szervezeten belül" - így a termékmenedzsmentet a gyárakhoz lehetett delegálni (177. old.).

A méretprobléma mellett más tényezốk is akadályozták a japán cégek divizionális szervezetté alakítását. Eloozoóleg említettük a termelési és elosztási funkciók elkülönítését. A tradicionális hálózatokon keresztül történő disztribúció elsôsorban választékgazdaságosságot biztosított, mivel ugyanazt az intézményrendszert tudták felhasználni többféle termék esetében. A marketing, az értékesítés, a $\mathrm{K}+\mathrm{F}$, a termelés és a logiszti$\mathrm{ka}$ - termékvonalak szerinti - szétosztása és divíziókba való átszervezése ily módon a japán modell szöges ellentétének tủnt. A japánok hierarchikus szellemú gondolkodásához is közelebb állt a funkcionális szervezeti struktúra. A keirecuk nem voltak olyan nagyméretúek és bürokratizáltak, ha pusztán a külön egységeket tekintjük: a csoportstruktúra volt az a tényezó (még ha virtuálisan is), ami terjedelmessé tette óket. Így ezeknek a határozottan elkülönülő egységeknek a stratégiája sokkal inkább egy specifikus termékvonal követésén alapult, mint a több termékcsaládot magában foglaló, széles választékon. A japán humánerőforrás-politika érdeke szintén az volt, hogy - amennyire csak lehetséges - ôrizze meg a rendszer centralizáltságát.

Összegezve az eddigieket: még a nagyméretú japán vállalatok is relatíve kicsinek és egyszerú szervezôdésünek tekinthetők az amerikaiakhoz képest, a legtöbbjük hatáskörileg erôsen centralizált funkcionális szervezeti struktúrában múködött és múködik. A II. világháborút követően még nem beszélhetünk globális jelenlétet és külföldi termelôkapacitásokat kiépító multinacionális vállalatokról Japánban (számos amerikai nagyvállalattól eltérốen). Az 1945-től 1952-ig tartó amerikai megszállás alatt a zaibacu holdingokat kisebb vállalatokra darabolták szét, így logikusnak túnt, hogy ezek az entitások vállalatközi és beszállítói hálózatokat szervezzenek, továbbá együttmúködjenek egymással a kutatás-fejlesztés, a marketing vagy az exportpiacokra irányuló értékesítés területén. Fruin (1994) szerint már az 1930-as évek vége felé „kialakult egy termékalapú beszállítói hálózat", amely a végtermékek értékének 5 és 65\%-a közötti részét képezte (134. old.). A nagyvállalatok haszna a beszállítók alacsonyabb béreinek, ugyanakkor versenyképes technikai színvonalának és a kis szervezetekre jellemző rugalmasságának volt köszönhetô. Az idézett szerző a következóképpen foglalja össze a japán vállalatok belsố strukturális fejlődését:

„Japánban - néhány emlitésre méltó kivétel mellett, mint például a Matsushita Electric Industrial - nem a multidivizionalitás jelentette a választ a modern üzleti vállalkozások növekvó komplexitásigényére. Ehelyett ...vállalatcsoportok jöttek létre, melyek tagjai kölcsönösen függtek egymástól, folyamatos üzleti kapcsolatban álltak, s ezt [a hálózatot] pénzügyi szálak füzték szorosabbra. A trösztellenes jogalkotás megakadályozta az összefonódó üzleti szövetségek kialakítását, a kölcsönös egymásrautaltság stratégiája azonban kifejezetten ezt támogatta. Az egyedi üzleti egységekre nem igazán volt az jellemzó, hogy naggyá és bürokratikussá nôtték ki magukat, a tulajdon elaprózódását pedig lehetóleg kerülték, így a vállalatok koncentráltak maradtak az energiaigény és az eróforrások tekintetében." (152. old.)

\section{A gazdasági buborék kipukkanása és a globális stratégiai szemlélet megjelenése}

Az előzó fejezetben azzal érveltünk, hogy a japán ipar nemzetköziesedése és felemelkedése átalakította a vállalati szférát, de ez az átalakulás nem jelentette a japán nagyvállalatok multidivizionális szervezetté tör- 
ténő egyöntetú fejlődését. Ennélfogva a vezetói kontextus sem változott drámai mértékben. Az erôs jen korszakának következményei túlmutatnak a divíziók kialakulásának kérdéskörén, ezért röviden áttekintjük ezt az időszakot.

Az öt fejlett ipari ország pénzügyminiszterei New Yorkban, 1985 szeptemberében találkoztak, hogy megoldják Japán óriási kereskedelmi többletének problémáját. Végül megegyeztek a jen árfolyamának felértékelésében. Ezt a megállapodást Plaza Egyezménynek nevezték, melynek következményeképpen egy éven belül a dollár értéke 240-ról 160-ra esett a jennel szemben (Ohtsu, 2002). Az amerikai szándék a japán export mesterségesen feltornázott versenyképességének ellensúlyozása volt. Úgy tûnt, az „ötök” stratégiája jobban bevált, mint amennyire várták, hiszen a dollár értéke zuhanni kezdett a jennel szemben, visszavetve ezzel a japán exportot. Ennek orvoslására a japán kormány szabadjára engedte a monetáris politikát, és drasztikusan alacsony szintre, 2,5\%-ra csökkentette a kamatlábat (Abegglen, 2006; Graham, 2004). A hitel olcsóvá és könnyen igényelhetôvé vált, ami egy új, zaitech-nek nevezett vállalati „divathoz” vezetett a japán cégek körében: spekulációs ügyletekkel és befektetések révén a vállalati vezetók nemegyszer nagyobb jövedelemre tettek szert, mint a szokásos üzleti tevékenységból. Hatalmas tókéket halmoztak fel és külföldi vállalatokat kezdtek felvásárolni, fóleg Amerikában és Európában. Az 1980-as évek végére a reálgazdaság elértéktelenedett a pénzügyi spekulációhoz viszonyítva. A vállalatok termelésük jelentős hányadát más, olcsó munkaerôt biztosító ázsiai országokba helyezték át, ami segített elkerülni az erôs jen negatív hatásait.

A végeredmény egy pénzügyi buborék formáját öltötte: a részvények és a földárak emelkedésével egy látszólag végtelen spirál alakult ki; ráadásul a bankhitelek fedezetéül is inkább ezek az ingatlanok és részvények szolgáltak, semmint a jövóbeli várható pénzáramlás. A buborék csúcspontján a tokiói tőzsde a világ teljes tőzsdei értékének több mint 40\%-át képviselte (Graham, 2004).

Amikor a japán jegybank számára világossá vált, hogy ez a pénzügyi manőver kicsúszott az ellenőrzése alól, 1989 és 1990 között duplájára emelte a kamatlábat - újra drámai hatást okozva ezzel: 1990 januárjában a tokiói tôzsde részvényárfolyamai drasztikus zuhanásnak indultak. A buborék kipukkadásának Japánra gyakorolt hatásai ismeretesek: nem egészen egy éven belül Japán elveszítette ,üzleti értékének” 30-60\%-át. A veszteség minden egyes piaci szereplő költségvetésében jelentkezett - egészen az októberi mélypontig: zuhant a vállalatok birtokában lévő részvények, ingat- lanok értéke, a háztartások vagyona, a bankok és más pénzügyi intézmények kintlévőségeinek behajthatósága kétségessé vált.

Japán pénzügyi buborékjának kipukkanása egyértelmúvé tette, hogy a szigetország elvesztette domináns szerepét mind a kereskedelem, mind pedig az ipari termelés vonatkozásában. A felemelkedő gazdaságok (Dél-Korea, Taiwan, Hongkong, a szárazföldi Kína stb.) új alternatívákat kínáltak a világ számára az olcsó munkaeróben és a jó minőségû termékekben. Amikor valami hasonló (tudniillik a megkérdójelezhetetlen üzleti hegemónia megtörése) zajlott le Amerikában az 1970-es és 1980-as években, az USA széles körú deregulációval és stratégiai paradigmaváltással válaszolt. Hogy ugyanez történt vagy történik-e Japánban, az igencsak kétséges.

Figyelemre méltó volt ugyanis a buborék kipukkadásakor az azonnali reakció hiánya. Az egyik vezető amerikai üzleti folyóiratban, a Harvard Business Review-ban például 1993-ig nem jelent meg cikk erról a fejleményról, és az elsố, a japán ipari termeléshez köthetô, kritikai élú tanulmány csak 1993 májusában jelent meg, meglehetősen visszafogott címmel (,Japanese Manufacturing", azaz Japán termelés). Egy kifejezetten a buborék kipukkadását felidéző, elhúzódó recessziót elemző cikket igen későn, 1993 novemberében jelentetett meg a HBR egy japán szerző tollából, amely tanulmány már megkérdójelezte a szigetország hosszú távú versenyképességét (Hori, 1993). Szintén az üzleti körök reakciójának kései voltát jelzi, hogy a japán bankok hanyatlásáról szóló első írás csak 1994 júliusára tehető.

Hogyan magyarázható ez a lassú reakcióidő? Egyrészrôl a Japán-USA relációban szinte minden szakértô a japán modellt dicsốitette az 1990-es évekig. Természetes, hogy késóbb is mindenki abban bízott: neki van igaza. Másfelốl a korábbi fölény annyira meggyőző volt, hogy néhány japán makrogazdasági mutató még az 1990-es évek első felében is kedvezónek túnt, miközben az amerikai kereskedelmi deficit folyamatosan csökkent. 1995-ben például 22 milliárd dollárnyi múködő tốke vándorolt Japánból az USA-ba (ebból hétmilliárd dollár az ipari termelésbe). Liker, Fruin és Adler (1999) szerint ennyit tett ki a teljes beruházási keret, amit közel 1700 gyár megnyitására, illetve bővítésére fordítottak szerte Amerikában. Egy ekkora volumenú beruházási kapacitás esetében továbbra is nehéznek tûnik Japán mély válságáról beszélni.

A buborék kipukkanása tehát lelohasztotta ugyan a Japán iránti általános lelkesedést, de nem tudta a válság általános érzetét kelteni sem az országon belül, sem azon kívül. Emiatt váratott magára a médiavisszhang. A válságintézkedések, a rossz hitelek leírása, valamint 
a bankok újratốkésítése csak az 1990-es évek végén, illetve az ezredfordulót követốen indultak meg. Ezalatt az idôszak alatt a válságkezelés költsége valószínúsíthetốn szintén megemelkedett.

Japán ugyanúgy elveszíteni látszik a versenyképességét a harmadik évezred hajnalán, mint ahogyan az Egyesült Államok vesztette el az 1970-es években. A vállalati környezet egyre inkább globálissá válik, és az újonnan iparosodott, fejlődő országok sikeresen váltják ki a japán export egy jelentôs részét. A japán munkaerô megdrágult, a vállalatok pedig nehézkesen reagálónak és rugalmatlannak túnnek. Újra valószínúnek látszik, hogy Japán - három évtizedes késéssel Amerikához képest - a paradigmaváltás kényszerével találja magát szemben (Black, 2010). A dereguláció fokozott igénye is ugyanúgy megjelent, mint korábban az USA esetében (Imai, 2011).

\section{Összefoglalás: az elméletre és a gyakorlatra vonatkozó következtetések}

Amikor Masao Hanaoka (1997) a vezetési rendszerek változását, fejlódését elemezte, a következóket írta a menedzsmentrendszerek elméleti erejére vonatkozóan. „A vezetési modellalkotó képesség egy egészen új vezetối magatartásrendszer létrehozásának képességét jelenti, ami kétségtelenül függ a fennálló körülményektől és a vezetók tapasztalatától. Már vannak példák a történelemben arra vonatkozóan, hogy a vezetői magatartás teljesen új formái alakultak ki a vezetési modellalkotó képességnek köszönhetően. A fennálló rutinok megtörése menedzsmentforradalmakat hozott létre, s ezek a korszakváltások olykor nemcsak a vállalati környezetre, hanem a fejlődési trendekre is hatással voltak" (156. old.).

A menedzsmentforradalmakat érzékeltettük az Egyesült Államok esetében a klasszikus vezetés/ taylorizmus, az emberi viszonyok tanának mozgalma, a nyílt rendszerek és a divizionalizálódás, illetve a globális verseny szakaszaival. Megkíséreltük bemutatni, hogy Japánban a menedzsmentforradalmak ritkaságszámba mentek az USA-val összehasonlítva, ahol szabályos idôközönként, 20-30 évente tapasztaltunk paradigmaváltást. Az átalakulások Japánban több évtizeddel késóbb mentek végbe, s az intézményi környezet jórészt tompította ezek forradalmi erejét.

A tudományos vezetés, mint új paradigma, relatíve korán (az 1910-es években) jelent meg Japánban szinte párhuzamosan Amerikával, de a tömegtermelés lehetôsége nélkül. A taylorizmus és a tudományos vezetés hatékony eszközöket biztosított a japán ipar növekedéséhez, s e módszereket aztán a japánok minden területen tökélyre fejlesztették: a gazdaságpolitikában, a vállalatokban és a háztartásokban egyaránt. Bár az elnevezés változott, a japán üzem- és munkaszervezési módszertan egy évszázadon keresztül ugyanaz maradt: a taylorizmus, a hatékonysági mozgalom, a racionalizáció, a termelốkapacitások bôvítése a háború alatt, a lean és a minôségbiztosítás mind a selejt csökkentését és a hatékonyság növelését irányozta elő. Következésképp a tudományos vezetés idôvel a japán társadalom szerves részévé vált. Módszereit ösztönösen alkalmazták, így azok már nem számítottak átvett, ,importált” technikáknak. Az 1930-as évekre a tudományos vezetés mély gyökereket „eresztett” Japánban, és elfogadott, uralkodó paradigmaként hatott ezután is, amely körülmény megnehezítette a késôbbi paradigmaváltásokat. Az eredeti taylorista módszerekben végbement változások ugyanazokat az igényeket elégítették ki, mint Amerikában a HR (Human Relations) mozgalom; nem volt szükség radikális szervezetátalakításokra, csak egyfajta szervezeti strukturális alkalmazkodásra, amikor a növekvő japán vállalatok nemzetköziesedése megindult és felgyorsult. A hagyományos vezetési elveket 1990-tól kezdve egyre többen kritizálták a japán ipar csökkenő versenyképessége miatt, de úgy túnik, még mindig a régi módszereket részesítik előnyben a japán vállalatok, a radikális átalakulás egyelôre elmaradt.

Azt is értsük meg, hogy a japán vezetési rendszer olyan korszakban alakult ki és fejlődött, amikor más országok ,utolérése”, a „piacok védelme” és a „hatékonyság biztosítása" voltak a japán gazdaságpolitika kulcsszavai. A mai japán vezetési gyakorlat ily módon számos elemet tartalmaz, amelyek gyökerei a robbanásszerú gazdasági fejlődés előtti időszakra nyúlnak vissza. Napjainkra az ország gazdasági pozíciója és nemzetközi státusa jelentôsen módosult: egy újabb kutatómunka tudná csak igazolni, hogy a mai japán társadalom milyen mértékben tekinti a jelenleg is alkalmazott vezetési módszereket elavultnak. Egy ilyen felmérés kutatási eredményei közelebb vinnének a Japánban szükséges reformok megértéséhez, illetóleg a közeljövő vállalatvezetési rendszerét érintő változások felvázolásához.

\section{Lábjegyzet}

*A tanulmány megjelenésével kapcsolatban köszönet illeti Tari Ernôt a lektorálás során nyújtott segítségéért.

${ }^{1}$ A paradigmákkal kapcsolatban 1. még Vaszkun (2012).

${ }^{2}$ L. (Nakase, 1979)

${ }^{3}$ A mátrix, a virtuális struktúrák és más alternatív szervezeti formák a funkcionális és divizionális megoldások további finomításaiként foghatók fel.

${ }^{4}$ Ezzel ellentétben a Lehman-válságot felidéző első cikket 2009 januárjában közölték, négy hónappal a cső́döt követően. 


\section{Felhasznált irodalom}

Abe, M. (2010): Introduction: Japanese Management in the 21st Century. in: Haghirian, P. (ed.): Innovation and Change in Japanese Management. Bansingstoke: Palgrave Macmillan: p. 1-11.

Abegglen, J.C. (1960): The Japanese Factory: Aspects of its Social Organization. Glencoe, Illinois: The Free Press

Abegglen, J.C. (2006): 21st century Japanese management: new systems, lasting values. New York: Palgrave Macmillan

Ahmadjian, C.L. - Robbins, G.E. (2005): A Clash of Capitalisms: Foreign Shareholders and Corporate Restructuring in 1990s Japan. American Sociological Review, Vol. 70 No. 3: p. 451-471.

Bellah, R.N. (1957): Tokugawa Religion: The Values of Preindustrial Japan. Free Press, available at: http://books. google.hu/books?id=4rkIAQAAIAAJ.

Benson, J. (2006): Convergence and Diversity: Emerging Patterns of Human Resource Management in Japan. in: Haak, R. (ed.): The Changing Structure of Labour in Japan, Bansingstoke: Palgrave Macmillan: p. 40-57.

Black, J.S. (2010): Sunset in the land of the rising sun: why Japanese multinational corporations will struggle in the global future. Basingstoke; New York, NY.: INSEAD Business Press, Palgrave Macmillan

Chandler, A.D.J. (1962): Strategy and structure: chapters in the history of the industrial enterprise. Cambridge, Mass.: M.I.T. Press

Cole, R.E. (1973): Japanese blue collar: the changing tradition. Berkeley: University of California Press

Dobák M. (1988): Szervezetalakítás és szervezeti formák: divizionális és mátrix-szervezetek. Budapest: Közgazdasági és Jogi Könyvkiadó

Dore, R.P. (1973): British Factory - Japanese Factory: The Origins of National Diversity in Industrial Relations. London: George Allen \& Unwin

Fruin, W. M. (1994): The Japanese enterprise system: competitive strategies and cooperative structures. Oxford; New York: Clarendon Press; Oxford University Press

Fujimura, H. (2006): Managing the Development of One's Own Vocational Skills. in: Haak, R. (ed.): The Changing Structure of Labor in Japan. Basingstoke; New York: Palgrave Macmillan: p. 107-121.

Gerschenkron, A. (1962): Economic backwardness in historical perspective: a book of essays. Cambridge, Mass.: Belknap Press

Gordon, A. (1998): The Wages of Affluence: Labor and Management in Postwar Japan. Cambridge and London: Harvard University Press

Graham, F. (2004): A Japanese company in crisis. Curzon, London and New York: Routledge

Hamada, T. (1991): American enterprise in Japan. Albany, New York: State University of New York Press
Hanaoka, M. (1997): The Characteristics of Japanese Style Human Resource Management. Global Studies in Management: A Japanese Perspective. Tokyo: Institute of Business Research, Daito Bunka University: p. 145178.

Hirschmeier, J. (1981): The development of Japanese business, 1600-1980. London; Boston: G. Allen \& Unwin

Hori, S. (1993): Fixing Japan's white-collar economy: A personal view. Harvard Business Review, Vol. 71 No. 6: p. 157-171.

Imai, J. (2011): The transformation of Japanese employment relations: reform without labor. Basingstoke, Hampshire; New York, NY.: Palgrave Macmillan

Imashiro, M. (1997): The History of Railway Construction and Management in Japan. Global Studies in Management: A Japanese Perspective. Tokyo: Institute of Business Research, Daito Bunka University: p. 1-76.

Itami, H. - Roehl, T.W. (1987): Mobilizing invisible assets. Cambridge, Mass.: Harvard University Press

Jacoby, S.M. (2007): The embedded corporation: corporate governance and employment relations in Japan and the United States. Princeton, N. J.; Woodstock: Princeton University Press

Johnson, C. (1982): MITI and the Japanese miracle: The growth of industrial policy, 1925-1975. Stanford: Stanford University Press

Keizer, A.B. (2011): Changes in Japanese employment practices: beyond the Japanese model. London; New York: Routledge

Keys, J.B. - Miller, T.R. (1984): The Japanese Management Theory Jungle. Academy of Management Review, Vol. 9, No. 2: p. 342-353.

Lee, G. $-Y$. (2000): Japanese Management Style in Achieving the Cost Reduction Targets, Japanese Cost Management. London: Imperial College Press: p. 397-415.

Liker, J.K. - Fruin, W.M. - Adler, P.S. (1999): Bringing Japanese Management Systems to the United States: Transplantation or Transformation? in: Liker, J. K. Fruin, W. M. - Adler, P. S. (eds.): Remade in America: Transplanting \& Transforming Japanese Management Systems. New York; Oxford: Oxford University Press: p. 3-38.

Marosi M. (1985): Japán vállalatok vezetése és szervezése. Budapest: Közgazdasági és Jogi Könyvkiadó

Marosi M. (1986): A japán vállalatok sikeres vezetési és szervezési módszereirôl. Vezetéstudomány, Vol. 17, No. 11: p. 22-28.

Marosi M. (2003): Japán, koreai és kínai menedzsment. Budapest: Aula

Maruyama, K. (1997): A Comparative Study of the Japanese Management Theories of Four scholars Masumi Tsuda, Hiroshi Hazama, Ryushi Iwata and Kuniyoshi Urabe. Global Studies in Management: A Japanese Perspective. Tokyo: Institute of Business Research, Daito Bunka University: p. 111-126. 
Matsumoto, D.R. (2002): The new Japan: debunking seven cultural stereotypes. Yarmouth, Me.: Intercultural Press

Miyamoto, K. (2008): International Management Accounting in Japan: Current Status of Electronic Companies. Singapore: World Scientific

Miyamoto, M. (1995): Straitjacket society: an insider's irreverent view of bureaucratic Japan. Tokyo; New York: Kodansha International

Móczár J. (1987): Gazdaságirányítás és tervezés japán módra. Budapest: Közgazdasági és Jogi Könyvkiadó

Nakane, C. (1970): Japanese society. Berkeley: University of California Press

Nakase, T. (1979): The Introduction of Scientific Management in Japan and its Characteristics. Labor and Management: Proceedings of the Fourth Fuji Conference. Tokyo: University of Tokyo Press: p. 171-202.

Nakatsumi, T. (1922): Kagakuteki kanrihou ni taisuru gensei hihan. Kokka gakkai zasshi, Vol. 36, No. 2: p. 130.

Ohtsu, M. (2002): Inside Japanese business: a narrative history, 1960-2000. Nanzan University academic publication series. Armonk, N.Y.: M.E. Sharpe

Olcott, G. (2011): Conflict and change: foreign ownership and the Japanese firm. Cambridge: Cambridge Univ Press

Pyle, K.B. (1996): The making of modern Japan. Lexington, Mass.: D.C. Heath
Shinpo, H. (2008): Historical development of Japanese companies: corporate governance and foreign investment. [S.1.]: Create Space

Totman, C.D. (2005): A history of Japan. Malden, Mass.: Blackwell Pub.

Tsutsui, W.M. (1996): W. Edwards Deming and the Origins of Quality Control in Japan. Journal of Japanese Studies, Vol. 22 No. 2: p. 295-325.

Tsutsui, W.M. (1998): Manufacturing ideology: scientific management in twentieth-century Japan. Princeton, N. J.: Princeton University Press

Tsutsui, W.M. (2001): The Way of Efficiency: Ueno Yoichi and Scientific Management in Twentieth-Century Japan. Modern Asian Studies, Vol. 35, No. 2: p. 441-467.

Vaszkun, B. (2010): How To Maintain Stable Employment in a Crisis Context? The Japanese Case. Conference paper: 6th International Conference for Young Researchers, Szent István University, Gödöllő, Hungary

Vaszkun, B. (2012): One Hundred Years of Management: American Paradigms and the Japanese Management "Reloaded". Dissertation. Budapest, available at: http:// phd.lib.uni-corvinus.hu/701/1/Vaszkun_Balazs_den.pdf. 